\title{
Amelioration of asthmatic inflammation by an aqueous extract of Spinacia oleracea Linn
}

\author{
JIN-CHUL HEO ${ }^{1 *}$, CHUL-HONG PARK ${ }^{2 *}$, HYUN-JIN LEE ${ }^{2}$, SI-OH KIM ${ }^{3}$, \\ TAE-HO KIM ${ }^{4}$ and SANG-HAN LEE ${ }^{1,2}$ \\ ${ }^{1}$ Food and Bio-Industry Research Institute and ${ }^{2}$ Department of Food Science and Biotechnology, \\ Kyungpook National University, Daegu 702-701; ${ }^{3}$ Department of Anesthesiology, Kyungpook \\ National University School of Medicine, Daegu 700-721; ${ }^{4}$ Skeletal Diseases Genome \\ Research Center, Kyungpook National University Hospital, Daegu 700-412, Korea
}

Received October 6, 2009; Accepted December 18, 2009

DOI: $10.3892 /$ ijmm_00000359

\begin{abstract}
Inflammation of the respiratory tract is a crucial process in immune diseases, including asthma, and atopic rhinitis. To establish whether an aqueous extract of Spinacia oleracea Linn (SoL) has a beneficial influence in terms of antiasthmatic activity, we examined its effects on an ovalbumininduced asthmatic model. Mice sensitized to ovalbumin were orally administered the SoL extract, and their lungs examined by hematoxylin and eosin staining to determine IL-4/13 cytokine expression. The SoL extract exerted strong antiasthmatic effects by inducing a decrease in the $\mathrm{CD} 4^{+}$cell number, IL-4/13, and other molecular markers in the lung. Our results collectively indicate that the aqueous SoL extract ameliorates asthmatic symptoms effectively in a mouse ovalbumin-challenge model.
\end{abstract}

\section{Introduction}

Reactive oxygen species (ROS) are pivotal in triggering particular degenerative diseases in cells (1). To expedite the reduction of radicals, antioxidants are required for specific degenerative diseases, such as asthma and chronic obstructive pulmonary disorders (2). ROS can attack random cells. Chronic asthma-related disorders arise, in cases where the radicals attack bronchoalveolar cells $(1,2)$.

Asthma is a classical disorder of the airway hyperresponses, originating from a $\mathrm{T}$-cell imbalance leading to

Correspondence to: Professor Sang-Han Lee, Department of Food Science and Biotechnology, Kyungpook National University, Daegu 702-701, Korea

E-mail: sang@knu.ac.kr

*Contributed equally

Key words: Spinacia oleracea Linn, asthma, inflammation, aqueous extract, ovalbumin-challenge model molecular inflammation (3). In bronchial asthma, various mediators induce the infiltration of mast cells, eosinophils and Th2 lymphocytes into lesions with downstream mediators, resulting in classical asthmatic phenotypes, such as mucous over-production, airway hyper-responsiveness, and submucosal thickness (4).

The spinach, Spinacia oleracea Linn, is well-known for its vitamin content. The alkaline vegetable contains carotene (the precursor of vitamin A), calcium, iodine and ferrous ions, and is considered suitable for children and pregnant women (5). Additionally, the vegetable has beneficial effects on anemia and constipation, due to its saponin, dietary fiber, ferric salt, and folic acid content. Folic acid and ferric salts in spinach have a potent anti-proliferation to combat stomach, colon, lung cancer $(5,6)$. A recent study shows folic acid in spinach exerts anti-hyperglycemic effects by removing homocysteine in the blood. Moreover, the vegetable not only inhibits DNA breakage due to oxidative stress, but also reduces damage to ischemic brains (7).

Herein, we demonstrate the potential of Spinacia oleracea Linn in alleviating asthmatic symptoms in vivo. The major finding of this study is that spinach exhibits antioxidant and anti-asthmatic activities in vivo and in vitro, as confirmed with data from antioxidant assays and evaluation IL-4, IL-13, $\mathrm{IgE}$, and $\mathrm{CD}^{+}$levels using several molecular biology experiments, including immunohistochemistry.

\section{Materials and methods}

Cell culture. For the MTT assay and antioxidant assay, murine melanoma B16 cells and SH-SY5Y neuroblastoma cells were cultured at $37^{\circ} \mathrm{C}$ under a humidified atmosphere of $5 \% \mathrm{CO}_{2}$ and $95 \%$ air in RPMI-1640 medium supplemented with $10 \%$ heat-inactivated fetal bovine serum, and $100 \mu \mathrm{g} / \mathrm{ml}$ of penicillin and streptomycin.

Animals and care. Mice weighing 25 $2.5 \mathrm{~g}$ (male, 7-week, Samtaco, Osan, Korea) were utilized. Each group was singly housed in cages. Animal care was performed as described previously, with slight modifications (8). All procedures were performed in compliance with the Guiding Principles in 
A

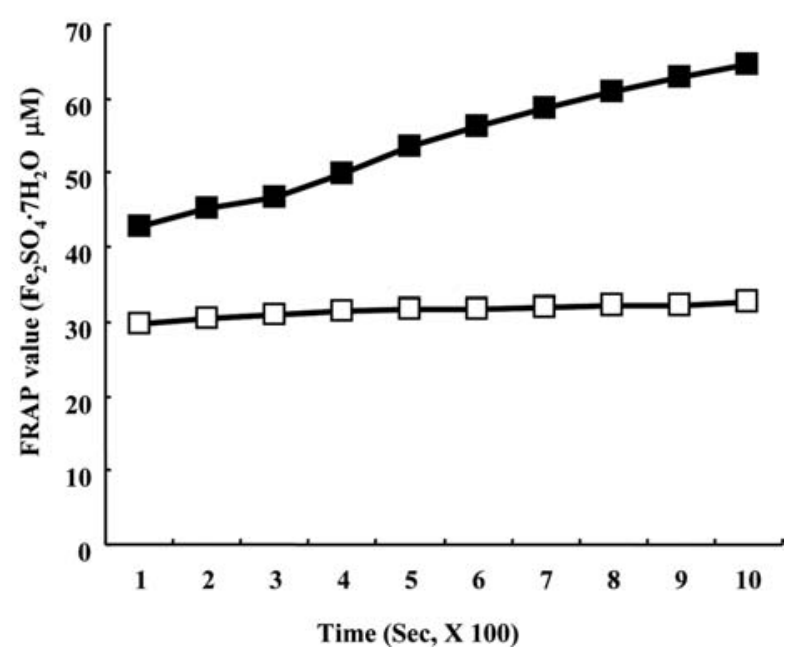

Figure 1. Antioxidant and protective effects of an aqueous extract of Spinacia oleracea Linn. (A) Reduction of the ferric-tripyridyltriazine $\left(\mathrm{Fe}^{3+}\right.$-TPTZ) complex into the ferrous $\left(\mathrm{Fe}^{2+}\right)$ form was accompanied by an intense blue color. Absorption was recorded at $593 \mathrm{~nm}$. (B) An aqueous extract of SoL enhanced cell proliferation activity under conditions of oxidative stress induced by hydrogen peroxide. Cells were subjected to oxidative stress with or without SoL extracts as indicated. After incubation, cell morphology was assessed using phase contrast microscopy or the MTT assay. No treatment (a and b), $500 \mu \mathrm{M} \mathrm{H}_{2} \mathrm{O}_{2}$ (c, d, e and f), and 25 antioxidant $1 / \mathrm{ml}$ of SoL extract (e and f). Scale bar, $100 \mu \mathrm{m}$; arrowheads, a crystal form of living cells; SoL, $25 \mu \mathrm{l} / \mathrm{ml}$ of Spinacia oleracea Linn extract. (C) Relative cell viability of SoL-treated SH-SY5Y neuroblastoma cells. *Significant differences from control, $\mathrm{p}<0.05$.

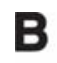

B

Phase contrast
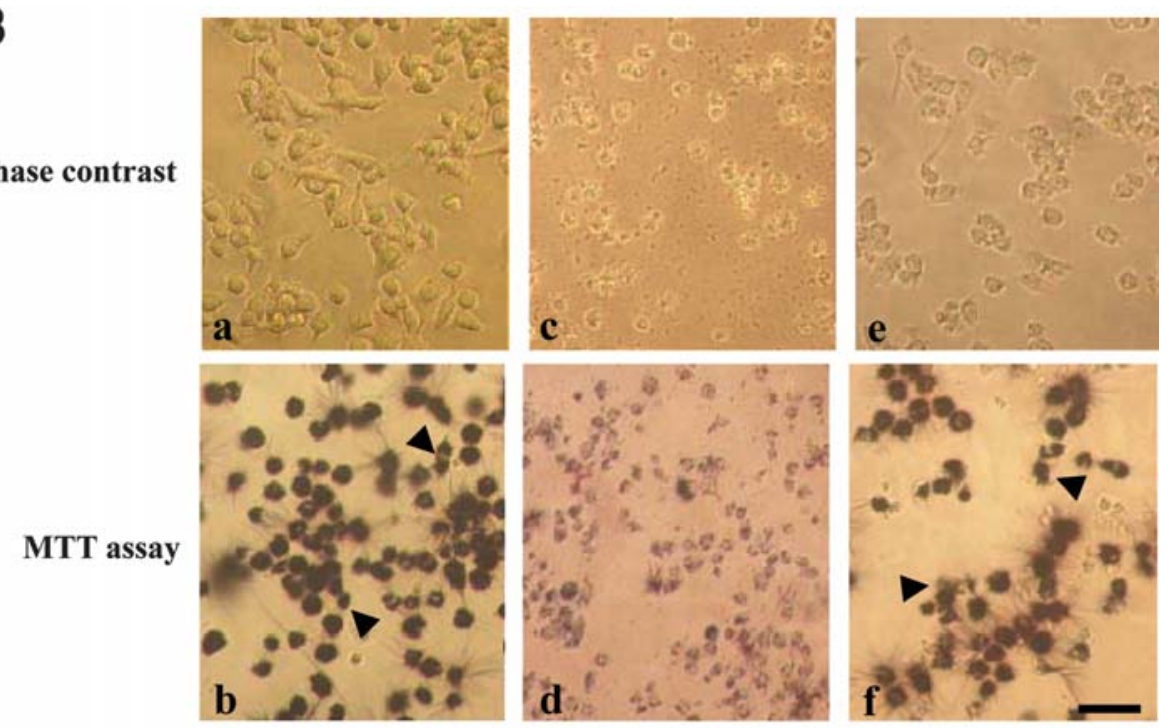

C

Control

$\mathrm{H}_{2} \mathrm{O}_{2}$

$\mathrm{H}_{2} \mathrm{O}_{2}+\mathrm{SoL}$

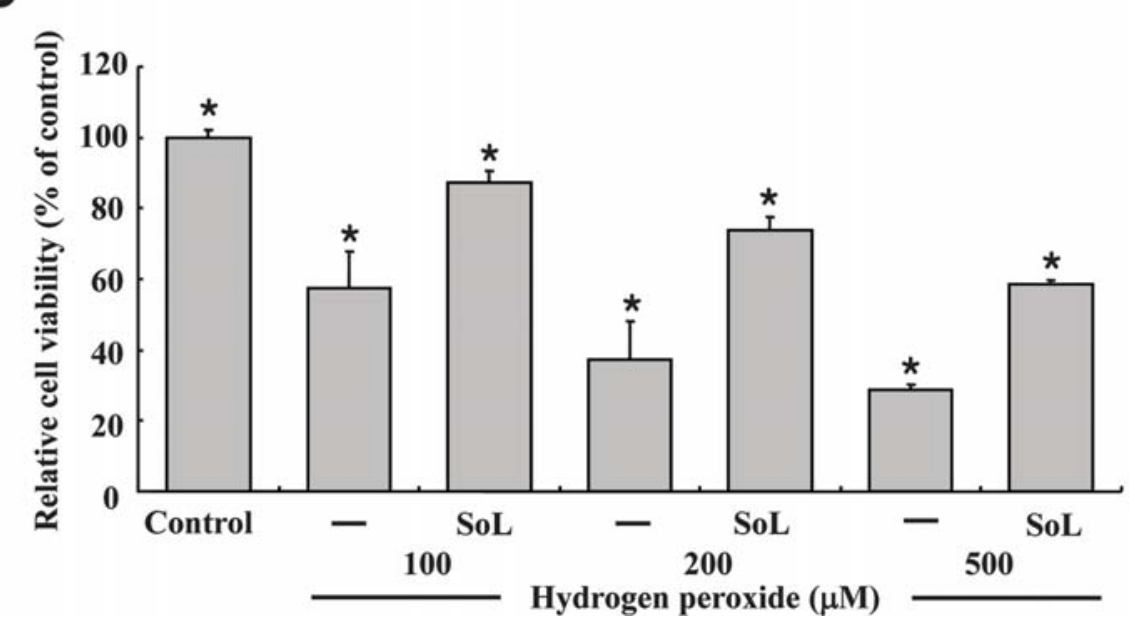

the Care and Use of Animals (National Research Council, 1996), the Animal Welfare Committee of Kyungpook National University, and KRIBB (NPRC) Committee for Animal Care. Animals received tap water and food ad libitum, and were maintained in a room under standard laboratory conditions $\left(23^{\circ} \mathrm{C} \pm 1^{\circ} \mathrm{C}\right.$ and $50 \pm 5 \%$ humidity) with a $12 \mathrm{~h}$ dark/light cycle. Rules for animal experiments, including ethical care, were strictly observed under guidance of the Committee. 
HE staining

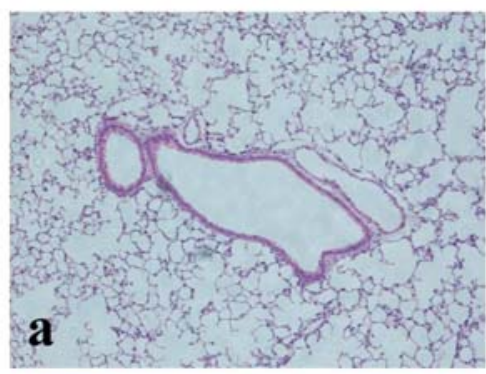

Control

OVA+SoL
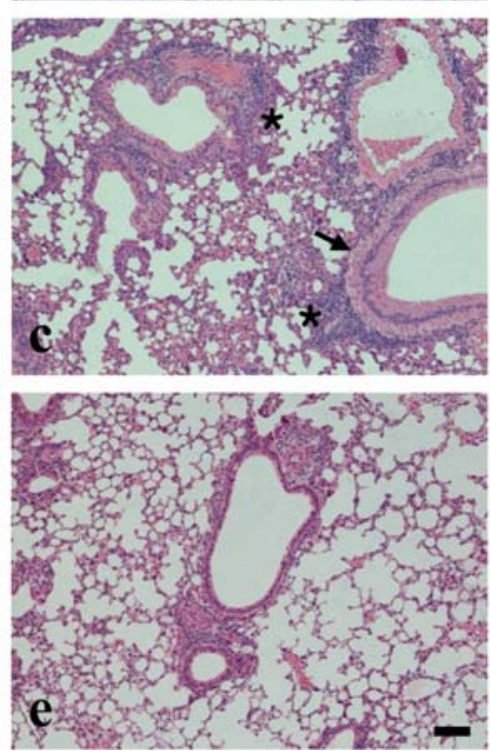

PAS staining
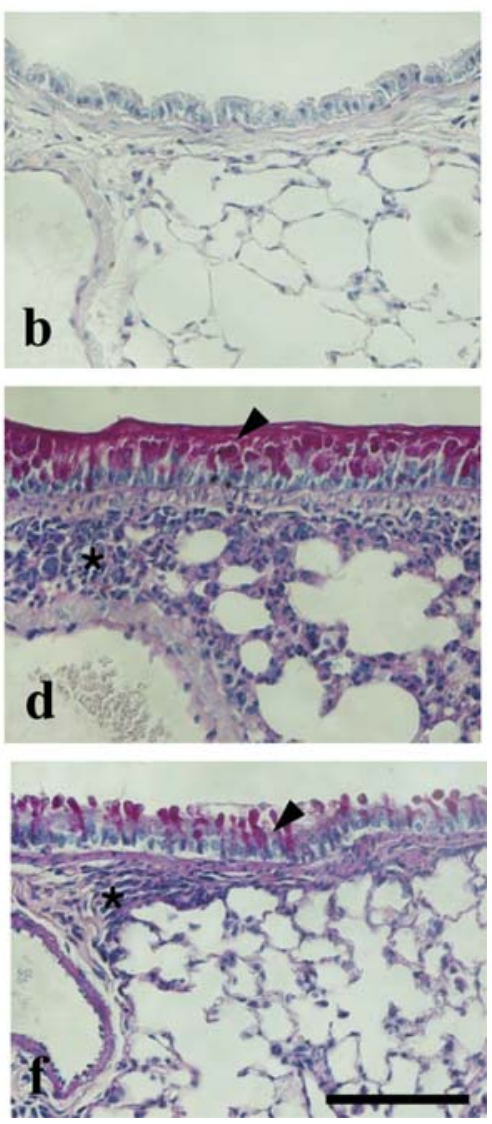

Figure 2. Comparison of asthmatic phenotypes using an aqueous extract of Spinacia oleracea Linn. Immunohistochemical analysis of an OVA-induced asthmatic mouse model revealed that the SoL extract inhibits $\mathrm{CD}^{+}$cells by controlling immune cell proliferation. H\&E-stained (a, c and e), PAS-responsive (b, d, and f) cells with or without SoL in lung tissue of the asthma mouse model. A part of the immune response (arrowhead, scale bar $=100 \mu \mathrm{m})$ is shown to present the exact distribution of asthma-related immune cells. OVA, ovalbumin-treated (100 $\mu \mathrm{g} / \mathrm{ml})$; SoL, $25 \mu 1 / \mathrm{ml}$ of the Spinacia oleracea Linn extract. Arrowhead is a site of mucus production. Arrow in c indicates airway thickness. Asterisks denote cell infiltration of $\mathrm{CD}^{+}{ }^{-}$-responsive cells, such as eosinophils.

Determination of FRAP value. An FRAP assay was adopted to measure the ferric-reducing ability of plasma at a low $\mathrm{pH}$ (14). Reduction of the ferric-tripyridyltriazine ( $\mathrm{Fe}^{3+}$-TPTZ) complex into the ferrous $\left(\mathrm{Fe}^{2+}\right)$ form was accompanied by an intense blue color. The FRAP reagent contained $10 \mathrm{mM}$ TPTZ solution in $40 \mathrm{mM} \mathrm{HCl}$ add equal volume of $20 \mathrm{mM}$ $\mathrm{FeCl}_{3}$ and 10 times of $0.3 \mathrm{M}$ acetate buffer. FRAP solution was freshly prepared. Samples $(10 \mu 1)$ were add to $200 \mu 1$ of FRAP solution, and then measured each $100 \mathrm{sec}$ at $0-1000 \mathrm{sec}$. The absorbance of the reaction mixture was at $595 \mathrm{~nm}$. The FRAP value of samples were calibrated with a ferrous sulfate $\left(\mathrm{Fe}_{2} \mathrm{SO}_{4} \cdot 7 \mathrm{H}_{2} \mathrm{O}\right)$ curve.

Preparation and fractionation of samples. Spinacia oleracea Linn was obtained from a Farm in Chilgok, Korea. The leaf was incubated in an oven at $60^{\circ} \mathrm{C}$ for $12 \mathrm{~h}$, and the dried leaf extracted with water $(1: 1 ; \mathrm{v} / \mathrm{v})$ for $18 \mathrm{~h}$, and centrifuged at $2,000 \mathrm{x} \mathrm{g}$ for $10 \mathrm{~min}$ to collect supernatant fractions before storage at $-70^{\circ} \mathrm{C}$. The supernatant fractions obtained were used for various in vitro and in vivo assays (data not shown). The plant was collected between September and November, 2005, and identified by a senior member of staff at the Department of Biology, Kyungpook National University, Daegu, Korea.
Voucher specimens of the plant have been deposited in the Enzyme Biotechnology Lab, KNU.

Cell protection by the SoL extract. Cell protective effects of the SoL extract were analyzed using the CCK-2 kit (Dojindo, ML) as follows: cells $\left(5 \times 10^{5}\right.$ cells $\left./ \mathrm{ml}\right)$ were plated on $96-w e l l$ plates, and incubated for $24 \mathrm{~h}$ in $100 \mu \mathrm{l}$ of RPMI medium. Various concentrations of extracts were added to cells and incubated for an additional $48 \mathrm{~h}$. Next, $10 \mu \mathrm{l}$ of MTT solution $(5 \mathrm{mg} / \mathrm{ml}$ MTT in PBS) was added to each well and incubated for a further $4 \mathrm{~h}$ at $37^{\circ} \mathrm{C}$. To terminate the reaction, $100 \mu 1$ of $0.04 \mathrm{M}$ $\mathrm{HCl}$ in isopropanol was added with vigorous mixing. Absorbance was determined on a VICTOR3 multilabel counter (Wallac, Turku, Finland) at $564 \mathrm{~nm}$ (9).

IL-4, IL-13, and IgE levels. The IL-4 and IL-13 concentrations were detremined using sandwich ELISA with slight modifications $(10,11)$. IgE was measured with a commercially available kit (AdB Serotec, Oxford, UK).

Ovalbumin-induced animal model. Mice underwent ovalbumin (OVA) sensitization and challenge using an earlier protocol with slight modifications (10-13). OVA $(100 \mu \mathrm{g} / \mathrm{ml}$ in saline, 
sterile filtered) was mixed with an equal volume of $10 \%(\mathrm{w} / \mathrm{v})$ aluminum potassium phosphate (alum, Sigma), and the $\mathrm{pH}$ adjusted to 6.5 with $10 \mathrm{~N} \mathrm{NaOH}$.

Histopathology and immunohistochemistry. Tissues were embedded in paraffin, cut into 4-6-mm sections, and set overnight on a slide warmer at $37^{\circ} \mathrm{C}$. Paraffin was removed by dipping in xylene 3 times for $10 \mathrm{~min}$. Dexylenation was additionally performed by dipping serially in 70-100\% ethanol for $60 \mathrm{~min}$. After washing, peroxidase bleaching was conducted via $1 \% \mathrm{BSA} / \mathrm{PBST}$ for $30 \mathrm{~min}$ at $4^{\circ} \mathrm{C}$. Hematoxylin and eosin (H\&E) staining was performed as described previously $(11,14)$. For each mouse, eight randomly-selected airways of the left lung were analyzed. For immunohistochemical analysis, lung tissues were fixed for $24 \mathrm{~h}$ in a $10 \%$ neutral-buffered formalin solution, and routinely processed. Paraffin sections were placed on Probe-On slides and incubated with methanol containing 3\% hydrogen peroxide to inhibit endogenous peroxidase activity. Tissue sections were treated with $10 \%$ normal goat serum for $1 \mathrm{~h}$ at room temperature to block non-specific binding. Slides were subsequently incubated overnight at $4^{\circ} \mathrm{C}$ with rabbit anti-IL-4 or anti-IL-13 antibody (SantaCruz Biotechnology; 1:200). Periodic Acid Schiff (PAS) staining was carried out, as described previously (10).

Eosinophil count. Eosinophil has a unique morphology in shape when the asthmatic event cause the number, therefore, we counted the numbers by comparing control and SoL-treated sample, as shown in detail with slight modifications (15).

Statistical analysis. Data are expressed as means \pm standard deviation. Statistical significance was determined with the Student-Newman-Keuls method for independent means, using the Microsoft Excel program (16). The critical level for significance was set at $\mathrm{P}<0.05$.

\section{Results and Discussion}

Herein, we examine whether an aqueous extract of Spinacia oleracea Linn (SoL) has the potential to improve asthmatic symptoms induced by ovalbumin challenge. Recently, we showed that SoL protects SH-SY5Y neuroblastoma cells against damage induced by hydrogen peroxide $(100 \mu \mathrm{M})$ or amyloid B-peptide $_{(1-42)}(20 \mu \mathrm{M})(9)$. We are convinced that SoL does not exhibit morphological toxicity at the tissue or organlevel, since it has been used as a table vegetable for decades. Anti-asthmatic in vivo assay was performed to evaluate the other unique activities of SoL extracts. In our study, repeated experiments consistently showed that the aqueous SoL extract effectively alleviated asthmatic activity.

Oxidative stress levels are increased in the respiratory tracts of children with asthma symptoms, including the lungs. Since oxidative attack of bronchial pathways is an initial step that triggers asthmatic symptoms (17), it is important to evaluate the molecular events underlying the inflammatory process and oxidative stress (18).

We theorized that, antioxidant activity is correlated with cell protection, resulting in inhibition of asthmatic characteristics. We first examined whether the SoL extract exhibit reducing ability of the ferric-tripyridyltriazine $\left(\mathrm{Fe}^{3+}-\right.$ TPTZ) complex into the ferrous $\left(\mathrm{Fe}^{2+}\right)$, which is a marker of the inhibition of molecular inflammation. As shown in Fig. $1 \mathrm{~A}$, the reducing power showed in time-dependent manner, whereas control had no activity. Hydrogen-peroxide (0 to $500 \mu \mathrm{M}$ ) was applied to SH-SY5Y neuroblastoma cells grown exponentially $24 \mathrm{~h}$ after splitting, and cell viability examined (Fig. 1B and C, and data not shown). As shown in Fig. 1Bc, hydrogen-peroxide $(500 \mu \mathrm{M})$ induced cell death. This phenomenon was clearly confirmed with the MTT assay (Fig. 1Bd). Conversely, following the addition of $25 \mu \mathrm{g} / \mathrm{ml}$ of SoL extract, the viable cell number recovered dramatically up to $45 \%$ higher than that observed in the presence of $500 \mu \mathrm{M}$ hydrogenperoxide onset (Fig. 1Be and Bf).

Next, anti-asthmatic effects were examined in vivo using an ovalbumin-induced mouse model. H\&E staining exposed clean tissue in control (Fig. 2a), but several immune positive cells around small parts of the lung in ovalbumin-treated tissue (Fig. 2c). PAS staining revealed similar patterns (Fig. 2d). The data clearly suggest that OVA-treated tissues have strong mucus production potential, which is significantly reduced in SoL-treated tissues (Fig. 2e and f). In contrast, the number of total immune cells from the group treated with SoL was lower than that in the ovalbumin-challenged lung tissues, as shown in Fig. 3A. CD4 ${ }^{+}$cells were additionally assessed by immunohistochemistry using a CD4 monoclonal antibody. The total $\mathrm{CD}^{+}$cell number was significantly reduced to that estimated using H\&E and PAS staining (Fig. 3B, and data not shown).

At the same time, the number of bronchoalveolar lavage (BAL) eosinophils was additionally confirmed by counting the cells under a phase contrast microscope (Fig. 3C). The data showed that the number of eosinophil was significantly lower than that of the SoL-treated group, indicating that SoL treatment decreased BAL's eosinophil expression (Fig. 3D). We also examined the expression patterns of matrix metalloproteinases (MMPs) to compare the basal levels of asthmatic molecular markers under anti-asthmatic conditions (data not shown).

To further evaluate whether the molecular markers related to asthma decrease during SoL treatment, IL-4, IL-13 and IgE levels in serum were measured using ELISA $(19,20)$. The IL-4 content was $91.5 \pm 20.9 \mathrm{pg} / \mathrm{ml}$ in the control group and $285.1 \pm 38.9 \mathrm{pg} / \mathrm{ml}$ in the ovalbumin-challenged group. This increase in the IL-4 level (up to 2.5 times) may be attributed to the ovalbumin-induced responses of immune cells. Treatment with SoL extracts suppressed the IL-4 level to approximately $45 \%$ (Fig. 4A). We clearly observed a $52 \%$ decrease in IL-13 expression in the group treated with ovalbumin plus SoL (Fig. 4B). ELISA data, confirmed by IgE expression in cells (Fig. 4C), show that the levels of asthma-related molecular markers are decreased by SoL in an ovalbumin-challenged mouse model. We also found that IL-4, IL-13, moreover IL-17E expression in SoL-treated lung tissues are lower than that in OVA-challenged tissues (data not shown).

In summary, we confirmed that the aqueous SoL extract exerts anti-asthmatic activity in vitro and in vivo by inhibiting asthma-related cytokine activity, as confirmed by $\mathrm{H} \& \mathrm{E}$ staining, IL-4/IL-13 ELISA and IgE excretion activity. The 
A

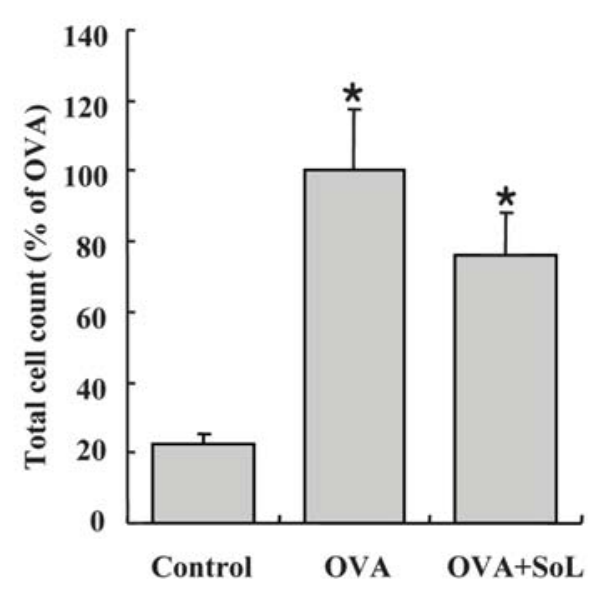

C

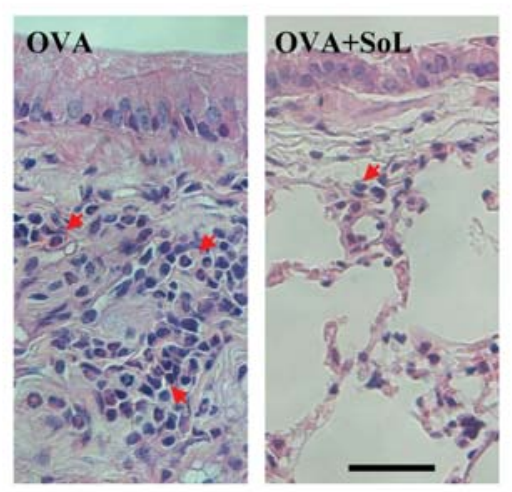

B

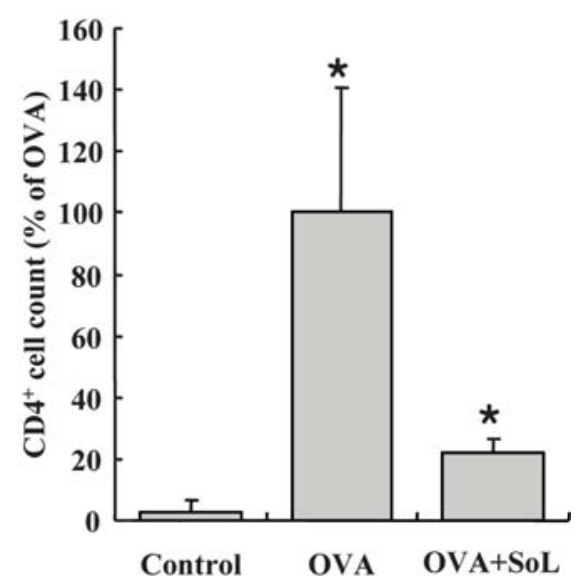

D

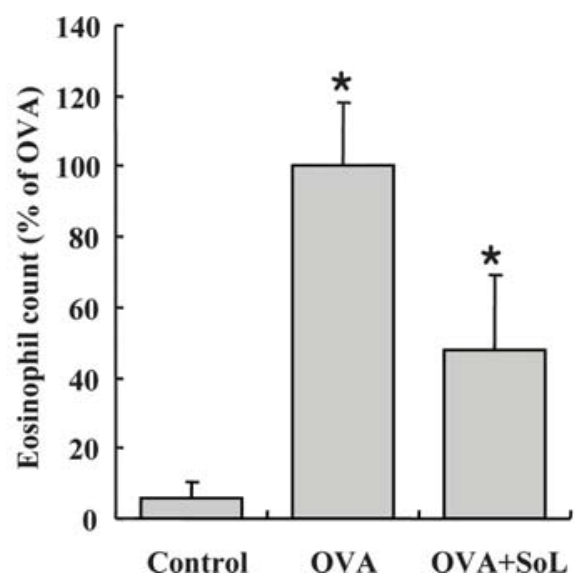

Figure 3. Anti-asthmatic effects of the aqueous extract of Spinacia oleracea Linn on an OVA-challenge asthmatic mouse model. Total cell count (A), CD4+responsive cells (B), cell infiltration (C), and eosinophil count (D) were measured by H\&E staining (A), immunohistochemical analysis (B), or counting the cells under a phase contrast microscope (C and D) as described in Materials and methods. OVA, ovalbumin-treated (100 $\mu \mathrm{g} / \mathrm{ml})$; SoL, $25 \mu 1 / \mathrm{ml}$ of Spinacia oleracea Linn extract. *Significant differences from OVA, $\mathrm{p}<0.05$.

A

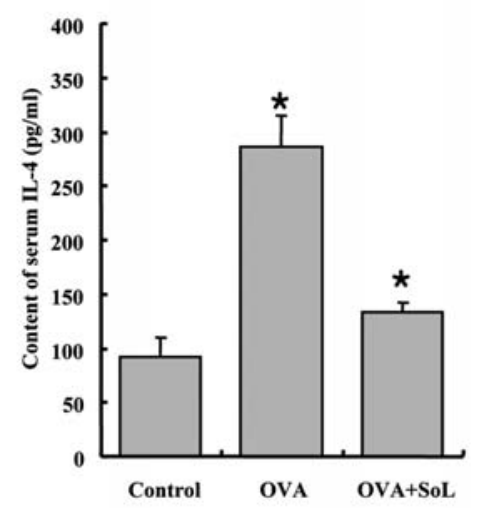

B

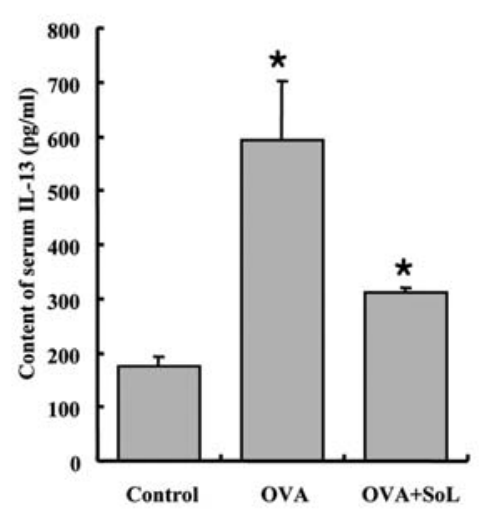

C

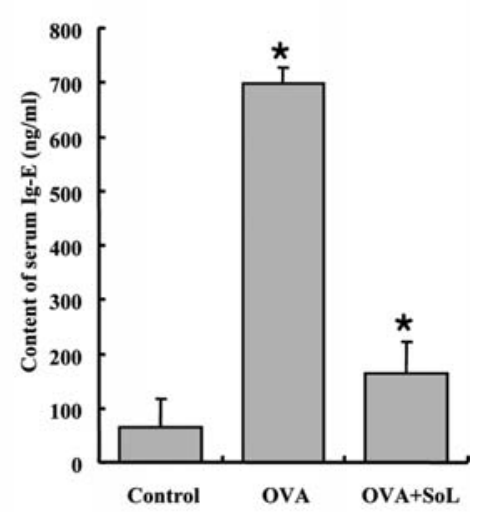

Figure 4. Expressions of anti-asthmatic effects of the aqueous extract of Spinacia oleracea Linn on an OVA-challenge asthmatic mouse model. Serum IL-4 (A), IL-13 (B), and IgE (C) levels were determined using ELISA, as described in Materials and methods. OVA, ovalbumin-treated (100 $\mu \mathrm{g} / \mathrm{ml}$ ); SoL, 25 $\mu 1 / \mathrm{ml}$ of Spinacia oleracea Linn extract. *Significant differences from OVA, $\mathrm{p}<0.05$.

precise atopic dermatitis mechanisms may be elucidated by manipulating anti-asthmatic activity via amelioration of asthma-related molecular signal(s). Future investigations should focus on the collection of potential anti-asthmatic compound(s) from SoL extracts, and subsequent purification on a large scale. 


\section{Acknowledgements}

This work was supported by the Technology Development Program for Agriculture and Forestry, Ministry of Food, Agriculture and Forestry, Republic of Korea (S.-H.L.), and in part by a grant from MAF/ARPC through the Grape Research Projects Group on in vitro assays (S.-H.L.).

\section{References}

1. Bast A, Haenen GR and Doelman CJ: Oxidants and antioxidants: state of the art. Am J Med 91: S2-S13, 1991.

2. Mak JC and Chan-Yeung MM: Reactive oxidant species in asthma. Curr Opin Pulm Med 12: 7-11, 2006.

3. Rahman I, Biswas SK and Kode A: Oxidant and antioxidant balance in the airways and airway diseases. Eur J Pharmacol 533: 222-239, 2006.

4. Greene LS: Asthma and oxidant stress: nutritional, environmental, and genetic risk factors. J Am Coll Nutr 14: 317-324, 1995.

5. Maeda N, Hada T, Murakami-Nakai C, Kuriyama I, Ichikawa H, Fukumori I, Hiratsuka J, Yoshida H, Sakaguchi K and Mizushina Y: Effects of DNA polymerase inhibitory and antitumor activities of lipase-hydrolyzed glycolipid fractions from spinach. J Nutr Biochem 16: 121-128, 2005.

6. Matsubara K, Matsumoto H, Iushinal M, Mori M, Nakajima N, Fuchigami M, Yoshida $\mathrm{H}$ and Hada $\mathrm{H}$ : Inhibitory effect of glycolipids from spinach on in vitro and ex vivo angiogenesis. Oncol Rep 14: 157-160, 2005.

7. Wang Y, Chang CF, Chou J, Chen HL, Deng X, Harvey BK, Cadet L and Bickford PC: Dietary supplementation with blueberries, spinach, or spirulina reduces ischemic brain damage. Exp Neurol 193: 75-84, 2005.

8. Hwang YK, Chun JS, Yoo PD, Ma JY, Hyun BH, Kim SU, Chang KT and Lee SH: Occlusal reduction of unilateral molars influences change of stress-related hormones in rats. Scand J Lab Anim Sci 31: 73-77, 2004

9. Park JY, Heo JC, Woo SW, Shin HM, Kwon TK, Lee JM, Chung SK and Lee SH: Spinacia oleracea extract protects against chemical-induced neuronal cell death. Kor J Food Presery 14: 425-430, 2007.
10. Wu AY, Chik SC, Chan AW, Li Z, Tsang KW and Li W: Antiinflammatory effects of high-dose montelukast in an animal model of an acute asthma. Clin Exp Allergy 33: 359-366, 2003.

11. Kim DY, Ryu SY, Lim JE, Lee YS and Ro JY: Anti-inflammatory mechanism of simvastatin in mouse allergic asthma model. Eur J Pharmacol 557: 76-86, 2007.

12. Lee E, Ha K, Yook JM, Jin MH, Seo CS, Son KH, Kim HP, Bae KH, Kang SS, Son JH and Chang HW: Anti-asthmatic activity of an ethanol extract from Saururus chinensis. Biol Pharm Bull 29: 211-215, 2006.

13. Choi JH, Oh SW, Kang MS, Kwon HJ, Oh GT and Kim DK: Trichostatin A attenuates airway inflammation in mouse asthma model. Clin Exp Allergy 35: 89-96, 2005.

14. Ponikau JU, Sherris DA, Kephart GM, Kern EB, Gaffey TA, Tarara JE and Kita H: Features of airway remodeling and eosinophilic inflammation in chronic rhinosinusitis: is the histopathology similar to asthma? J Allergy Clin Immunol 112: 877-882, 2003.

15. Yao T, Kojima Y, Koyanagi A, Yokoi H, Saito T, Kawano K, Furukawa M, Kusunoki T and Ikeda K: Eotaxin-1, -2, and -3 immunoreactivity and protein concentration in the nasal polyps of eosinophilic chronic rhinosinusitis patients. Laryngoscope 119: 1053-1059, 2009.

16. Falkeholm L, Grant CA, Magnusson A and Moller E: Xylenefree method for histological preparation: a multicentre evaluation. Lab Invest 81: 1213-1221, 2001.

17. Huang D, Ou B and Prior RL: The chemistry behind antioxidant capacity assays. J Agric Food Chem 53: 1841-1856, 2005.

18. Aruoma OI: Methodological considerations for characterizing potential antioxidant actions of bioactive components in plant foods. Mutat Res 523-524: 9-20, 2003.

19. Striz I, Mio T, Adachi Y, Robbins RA, Romberger DJ and Rennard SI: IL-4 and IL-13 stimulate human bronchial epithelial cells to release IL-8. Inflammation 23: 545-555, 1999.

20. Heo JC, Woo SW, Kweon MA, Park JY, Lee HK, Son M, Rho JR and Lee SH: Aqueous extract of the Helianthus annuus seed alleviates asthmatic symptoms in vivo. Int J Mol Med 21: 57-61, 2008. 